\title{
The influence of swimming learning method using swimming board towards students' interest in freestyle
}

\author{
Tjung Hauw Sin *, Fakhrina Hudayani \\ Faculty of Teacher Training and Education, Universitas Negeri Padang \\ Jalan Prof. Dr. Hamka, Air Tawar Padang, Sumatera Barat, 25132, Indonesia \\ * Corresponding Author. Email: thj_sin@yahoo.com
}

Received: 17 September 2020; Revised: 20 October 2020; Accepted: 18 December 2020

\begin{abstract}
The problem in this study is the lack of student interest in freestyle swimming. This study aimed to investigate the effect of swimming learning methods using swimming boards and interest in freestyle swimming skills. This type of research is quantitative using quasi-experimental research with a population of elementary school students in the city of Padang, sampling techniques using random purposive sampling, amounting to 26 people, determining groups' distribution by matching techniques. The study design was carried out pre-test, then treated for 14 meetings and carried out post-test. The test instrument used was the ability to swim freestyle. Using a normality test (liliefors) and data analysis techniques with the t-test, at a significant level $(\alpha=0.05)$. Then the results of the study showed that: (1) There was a significant influence between the learning methods using the swimming board on students' interest in freestyle swimming, with the results of t-count (15.37)> t-table (1.81).
\end{abstract}

Keywords: swimming boards, interests

How to Cite: Sin, T., \& Hudayani, F. (2020). The influence of swimming learning method using swimming board towards students' interest in freestyle. Jurnal Keolahragaan, 8(2), 216-221. doi:https://doi.org/10.21831/jk.v8i2.34412

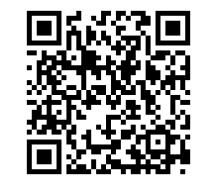

\section{INTRODUCTION}

Sport is one aspect that can not be separated from human life (Mirhan \& Jusuf, 2016). This is because the sport is a part of human life that can improve humans' physical condition both physically and spiritually, provide pleasure and provide health for humans, and a means of recreation (Scurati et al., 2019). Exercise for freshness requires physical activity or activities that are heavier than for health. One sport that is very popular with children, adolescents, and adults is swimming (Potop et al., 2018).

Swimming is fun, and swimming is one of the physical activities that improve the child's body's coordination and balance. Other benefits of swimming for children also make the heart and lungs stronger(Armen \& Rahmadani, 2019; Febrianta, 2016).

There are so many benefits of swimming for children, including (1) Exercising muscles, when the child is in the water, moving alone must spend twice as much energy as it opposes water force. That is, swimming makes the child move all his muscles. Movement after movement helps the development of muscles and makes the child stronger. (2) Confidence, being in the water and managing balance make children listen to their bodies. When a child can master even mild movements of swimming styles. This can help improve confidence, and high self-confidence can make children have good self-control, a greater desire for success, and comfort themselves in different social situations. (3) Survival skills, learning to swim since childhood will equip the body with survival skills crucial in water. This will make children have more experience in the water if at any time in an emergency. (4) Increase the heart and lungs' strength, and swimming is also an excellent sport for heart health and lungs. When swimming, children are trained to regulate breathing while in the water and raise their heads. If done routinely, this can improve heart strength and lungs. (5) Prevent obesity; obesity in children can reduce their flexibility in physical activity. Swimming can help prevent obesity. (6) Mental health, not only for physical but swimming, is also suitable for mental health children. Swimming can make a child's mood betterovercoming depression. Being in the water makes children feel relaxed and free to express themselves. (7) Improve cognitive function, movement when swimming helps the development of brain nerves in the corpus. That is why swimming can improve cognitive function or thinking ability in children. This 
will affect the ability to read, speak, academic learning, to spatial awareness. (8) Improve coordination and balance; of course, when in the water, children must coordinate and maintain balance. It is not easy to move arms and legs in tune. (9) Better sleep quality; no need to be surprised if children eat more deliciously sleep better after swimming. The energy expended when swimming makes them sleep better.

Swimming can be done at all age levels ranging from children, adolescents, adults to the elderly. One form of motion learning in physical education in elementary schools is swimming (Cardon et al., 2004; Gould et al., 1985). Through swimming, children have the opportunity to know and understand their environment. Children also get the opportunity to move freely, because inevitably, he must move his entire body (Opondo \& Shapiro, 2019). The aim is so that the body can float and move. Discretion is an extraordinary stimulus from the physical aspect and the mental aspect (Button et al., 2019; Hine et al., 2019).

Swimming has four styles, namely (1) breaststroke, (2) freestyle, (3) backstroke, and (4) butterfly style, but in swimming learning in elementary freestyle learned, freestyle is considered a style which is easy to learn (Elena-Diana \& Vladimir, 2019; Yani et al., 2019; Zecha et al., 2019). With the introduction of water methods, it is expected to launch swimming activities and master the basic movements in swimming. The first lesson in the introduction of water, recognize the water by touching it from the top of the pool, then enter the shallow pool slowly, after the whole body enters the pool, followed by the introduction of breathing in water, float, glide and then recognize the styles in swimming (Badruzaman, 2019; Kotlyarov, 2019; Saputra et al., 2019).

Freestyle is swimming with the chest position facing the surface of the water. Both arms are alternately moved further forward by pedaling, while both legs are alternately whipped up and down up and down. Freestyle swimming techniques are (1) The feet keep moving (may not stop), even breathing. (2) Right, and left hands move continuously alternately (without pauses or breaks). (3) The position of the palm slightly facing outward when it will touch the surface of the water. So as if the tip of the thumb touching the surface of the water first. (4) When the head turns to the right (or left) to take a breath, immediately move the head back immediately into the water. Do not wait for the right hand (left hand) to finish. (5) This freestyle can be faster, and the movements more stable; breathing is done after 2-3 sets of hand movements. So do not once natural hand movements take a breath.

Many methods are used in swimming sports learning, including using the swimming board (Stets et al., 2020). Using a swimming board is a learning method that uses a swimming board made of fiber, which floats on the surface of the water (Mu et al., 2019). The learning method using the swimming board is thought to provide an increase in the process of students' interest in learning freestyle swimming with useful techniques.

Interest is an impulse or desire in someone on a particular object (Ayom \& Suryobroto, 2019; Fatuhrahmah et al., 2020). For example, interest in learning, sports, or hobbies. Interests are personal (individual). This interest is not static or stops, but it is dynamic, and experiences ups and downs. Interest is also not innate, but something that can be learned. Something that was not previously desirable; can turn into something desirable because of specific inputs or new insights and new thinking patterns (Irmawati, 2018). This interest is closely related to one's motivation, something that is learned. It can also change depending on the needs, experience, and fashion that is a trend, not innate from birth. Factors that influence the emergence of one's interests depend on physical, social, emotional needs, and also experience. Interest begins with feelings of pleasure and a positive attitude(Elena-Diana \& Vladimir, 2018).

After the researchers observed and interviewed the school's physical education teacher, students' interest in freestyle swimming ability was minimal. The lack of infrastructure means that students lack interest in swimming freestyle because students only learn theory, and practice is practically never. Therefore, researchers are interested in researching by providing swimming learning methods using swimming boards to students' interest in freestyle swimming.

Thus, interest in learning is a significant factor in student learning success. Besides that, interest in learning can also support and influence the teaching and learning process in schools. However, in practice, not a few Physical Education teachers find obstacles in the classroom due to the lack of student interest in Physical Education learning, especially freestyle swimming. If this happens, the teaching and learning process will experience obstacles in achieving learning objectives (Saputra et al., 2019). By the problems raised, the formulation of the problem in this study (1) Does the method of learning swimming using a swimming board affect the students' interest in freestyle swimming? This study aims to: (1) 
Jurnal Keolahragaan 8 (2), 2020 - 218

Tjung Hauw Sin, Fakhrina Hudayani

Determine the effect of swimming learning using swimming boards on students' interest in freestyle swimming.

\section{METHOD}

This type of research is included in the quantitative method of quasi-experimental research (Avolio et al., 2009; Boettger \& Lam, 2013; Fatchurrohman, 2017). Aims to obtain information that is an estimate for information obtained by actual experiments in circumstances that do not allow to control or manipulate all relevant variables (Hasanah, 2017). The sampling technique uses a random purposive sampling technique. The sample of research is 26 students. Sampling according to the needs of researchers.

The instrument used in the study was a student questionnaire of interest in freestyle swimming before and after going through the learning process. This research formulates one hypothesis, namely There is a significant influence of swimming learning methods using swimming boards on students' interest in freestyle swimming. The t-test formula hypotheses test hypotheses. Before an analysis is performed, the analysis requirements test is first performed, namely the normality test and the linearity test.

\section{RESULT AND DISCUSSION}

The freestyle swimming technique is the most efficient of the other styles because the hands and feet are used differently, providing a resting phase during recovery. In freestyle, swimming is a style that uses a swinging motion of the hand over the water surface or a crawl style. The advantage of freestyle swimming is that it is the most efficient arm stroke pattern, has low water resistance, and has an efficient movement pattern. Internal factors come from the swimmer himself, such as physical condition, technique, tactics, and mentality. Meanwhile, external factors include the quality of the trainer or teacher, existing facilities and infrastructure, and the environmental conditions in which the teaching and learning process takes place. The same thing was also continued by a swimming performance, which is not easy to achieve because many factors determine swimmer achievement, such as anatomical factors; physiological factors; biomechanical factors; psychological factors (Rezki et al., 2019).

Students, there are still many mistakes made by students, such as in body position, namely the swimmer's body position is not parallel to the water surface. The swimmer's body cannot float properly, making it difficult to swim. The error that occurs in the breathing movement is that the head is too lifted when the breath is taken, causing the body to drop, making swimming heavier. In comparison, the errors that occur in the coordination movement are that after doing hand movements and foot movements. The swimmers do not make movements, or the swimmers appear to be slowing down in carrying out the movements resulting in the movements being not harmonious and regular, so they do not make the swimmer move forward and look stifled (Rezki et al., 2019).

The swimming board is a medium used to facilitate students in learning to crawl stroke swimming. The use of buoys in learning swimming can improve freestyle swimming skills. Meanwhile, another opinion states that the use of tools in the form of frog legs, buoys, paddles, and pull buoys significantly helps buoyancy, making it easier to master basic swimming techniques. Thus the attention to learning swimming can be focused on leg movement techniques and arm movements (Apriliyanto, 2017).

Based on the results the ability of students' interest in freestyle swimming collected through the results of a student interest analysis test (Table 1), against a sample of 26 students, the highest results were seen at 15.10, and the lowest score was 9.0, an average of 8.70, and a standard deviation of 1.65.

Table 1. Data on student interest in freestyle swimming

\begin{tabular}{clcc}
\hline No. & \multicolumn{1}{c}{ Interval } & Absolute Frequency $(\mathrm{Fa})$ & Cumulative Frequency $(\%)$ \\
\hline 1. & $9.0-10.7$ & 3 & 11.54 \\
2. & $10.8-12.8$ & 7 & 26.92 \\
3. & $12.9-14.9$ & 6 & 23.08 \\
4. & $14.10-15.10$ & 10 & 38.46 \\
& & $\mathbf{2 6}$ & $\mathbf{1 0 0}$ \\
\hline
\end{tabular}

Swimming is a versatile sport that can be done with various styles, distances, and difficulty levels (Potop et al., 2018). If the swimmer is a beginner, the swimmer is advised to try freestyle swimming 
near periodic breaks. Applying the right freestyle to swimming is beneficial for the muscles and breathing and helps swimmer be ready good at swimming. Other than that, swimming can also lose weight and increase in height. This happens because almost all the body muscles are involved when swimming (Armen \& Rahmadani, 2019; Elena-Diana \& Vladimir, 2018).

Freestyle is swimming with the swimmer's chest facing the surface of the water. Both arms are alternately moved further forward in a pedaling motion, while both legs are alternately whipped up and down up and down. Freestyle is the fastest swimming style compared to other styles. Freestyle is swimming with the chest facing the surface of the water (Born et al., 2020). Both sidearm alternately moved further forward with pedaling, while the two sides the feet alternately "whipped" up and down. When swimming freestyle, face position facing the surface of the water. Breathing is done when the arms are moved out of water. When the body becomes tilted and the head turns to the side. When taking a breath, swimmers can choose to turn left or right. Compared to other swimming styles, freestyle is a swimming style that can make the body go faster in water (Kasih et al., 2020).

Interest in learning is a psychological aspect of a person who manifests itself in several symptoms, such as (1) passion; (2) desire; (3) enthusiasm; (4) feeling, like to do the process of behavior change through various activities which include seeking knowledge and experience, in words Another interest in learning is attention, like, someone's interest (learning citizens) to the learning process that is lived and which is then shown through enthusiasm, participation, and activity in following the existing learning process. An activity carried out that is not following the interests will result in an unpleasant achievement. It can be said that fulfilling one's interest will get pleasure and inner satisfaction that can lead to motivation. Interest can also be a motivating force. A person's achievement is always influenced by the type and intensity of his interests. Interest causes satisfaction. A child tends to repeat the actions based on interests, and these interests can last for life (Ardiansyah et al., 2018).

A person's interests can be seen from the various objects or activities he chooses. The chosen activity will see how the person acts, pays attention, and performs activities related to the object. One of the activities that elementary school students are interested in is swimming, but students usually only learn theories. The practice in swimming learning in schools is minimal, even not at all.

This is due to the infrastructure and safety factors that do not support logging into swimming pools. Some of the schools and teachers give some meetings to do direct learning to the pool. This makes students' interest increasingly accompanied by using swimming board aids that make students not feel afraid to enter the pool. If a person is interested in an object, the person will focus their psychic energy on an object.

The research results that have been done by providing the initial test and conducting the exercise for fourteen meetings conducted the final test then in the test with the t-test formula. The data results can be explained that the student's interest in improving the ability of freestyle swimming students can be seen that significantly the learning of swimming using swimming boards affects the ability of freestyle swimming students. Hypothetical results indicate that $\mathrm{t}$-count $(15.37)>\mathrm{t}$-table (1.81). This explains swimming learning methods using swimming boards more effectively, one of which is to improve students' freestyle swimming skills.

\section{CONCLUSION}

From the results of the hypotheses and discussion of the researchers' results, it can be concluded that is Significantly learning to swim using a swimming board affects the ability of students' freestyle swimming. Hypothesis results show that t-count $(15,37)>t$-table $(1,81)$. Suggestion; Based on this researcher's results, it is recommended: (1) to the sports teacher who teaches to give the two exercise models to improve students' freestyle swimming skills. (2) In order for further researchers to conduct further research by using larger samples, longer research time, and better training programs so that students' freestyle swimming abilities are increased.

\section{REFERENCES}

Apriliyanto, R. B. (2017). Pengaruh penerapan alat bantu pull buoy dan papan luncur terhadap hasil belajar renang gaya bebas (crawl stroke) (Studi pada siswa kelas VII SMP Pahlawan Mojosari, Kab. Mojokerto). Jurnal Pendidikan Olahraga Dan Kesehatan, 5(2), 192-197. https://jurnalmahasiswa.unesa.ac.id/index.php/jurnal-pendidikan-jasmani/article/view/21241 
Ardiansyah, A., Suherman, A., \& Saptani, E. (2018). Pengaruh model pembelajaran hellison dalam penjas terhadap sikap tanggung jawab siswa di sekolah dasar. SpoRTIVE (Sport, Research, Treatment, Innovation of Learning and Value Education), 3(1), 1-10. https://ejournal.upi.edu/index.php/SpoRTIVE/article/view/13319

Armen, M., \& Rahmadani, A. F. (2019). Development of learning media swimming freestyle based on macromedia flash 8 on students class VIII SMPN 2 Padang. KnE Social Sciences, 3(15), 205. https://doi.org/10.18502/kss.v3i15.4368

Avolio, B. J., Reichard, R. J., Hannah, S. T., Walumbwa, F. O., \& Chan, A. (2009). A meta-analytic review of leadership impact research: Experimental and quasi-experimental studies. The Leadership Quarterly, 20(5), 764-784. https://doi.org/10.1016/j.leaqua.2009.06.006

Ayom, N. A., \& Suryobroto, A. S. (2019). Minat siswa kelas VII SMPN 1 Piyungan terhadap pembelajaran pendidikan jasmani olahraga dan kesehatan dengan Kurikulum 2013. Pendidikan Jasmani Kesehatan Dan Rekreasi, 8(3). http://journal.student.uny.ac.id/ojs/index.php/pjkr/article/view/14714

Badruzaman, B. (2019). The increase of swimming distance ability using tools for flippers \& back buoys and kickboard on freestyle swimming learning for sports science students beginners. Proceedings of the 3rd International Conference on Sport Science, Health, and Physical Education (ICSSHPE 2018). https://doi.org/10.2991/icsshpe-18.2019.97

Boettger, R. K., \& Lam, C. (2013). An overview of experimental and quasi-experimental research in Technical Communication Journals. IEEE Transactions on Professional Communication, 56(4), 272-293. https://doi.org/10.1109/TPC.2013.2287570

Born, D.-P., Stöggl, T., Petrov, A., Burkhardt, D., Lüthy, F., \& Romann, M. (2020). Analysis of freestyle swimming sprint start performance after maximal strength or vertical jump training in competitive female and male junior swimmers. Journal of Strength and Conditioning Research, 34(2), 323-331. https://doi.org/10.1519/JSC.0000000000003390

Button, A., Button, C., Maraj, B., Jackson, A.-M., \& Cotter, J. (2019). Developing a first principles approach to educating water skills for life to children. In Project Report No. 1-46. http://hdl.handle.net/10523/8981

Cardon, G., Verstraete, S., De Clercq, D., \& De Bourdeaudhuij, I. (2004). Research Note: Physical activity levels in elementary-school physical education: A comparison of swimming and nonswimming classes. Journal of Teaching in Physical Education, 23(3), 252-263. https://doi.org/10.1123/jtpe.23.3.252

Elena-Diana, S., \& Vladimir, P. (2018). Methodological aspects of learning the freestyle swimming at physical education and sport subject in the higher education of other profiles. Ovidius University Annals, Series Physical Education and Sport/Science, Movement and Health, 18(2), 403-408. https://www.analefefs.ro/en/anale-fefs/2018/i2supliment/autori/SIMA_ELENADIANA__POTOP_VLADIMIR.PDF

Elena-Diana, S., \& Vladimir, P. (2019). Biomechanical characteristics of the start in backstroke swimming style in the students of higher education of other profiles. Ovidius University Annals, Series Physical Education \& Sport/Science, Movement \& Health, 19(1), 37-43. https://www.analefefs.ro/anale-fefs/2019/i1/pe-autori/SIMA_ELENADIANA__POTOP_VLADIMIR.PDF

Fatchurrohman, R. (2017). Pengaruh motivasi berprestasi terhadap kesiapan belajar, pelaksanaan prakerin dan pencapaian kompetensi mata pelajaran produktif. Innovation of Vocational Technology Education, 7(2), 164-174. https://doi.org/10.17509/invotec.v7i2.6292

Fatuhrahmah, U., Darusmin, D. F., \& Widiana, H. S. (2020). The intertwining of vocational aptitude and interest: A study among university students in Indonesia. Psychology, Evaluation, and Technology in Educational Research, 3(1). https://doi.org/10.33292/petier.v3i1.58

Febrianta, Y. (2016). Alternatif mengembangkan kemampuan motorik kasar anak usia dini dengan aktivitas akuatik (berenang). Al-Athfal: Jurnal Pendidikan Anak, 2(2), 85-95. http://ejournal.uin-suka.ac.id/tarbiyah/index.php/alathfal/article/view/1269

Gould, D., Feltz, D., Horn, T., \& Weiss, M. (1982). Reasons for attrition in competitive youth 
swimming. Journal of Sport Behavior, 5(3), 155.

Hasanah, H. (2017). Teknik-teknik observasi (Sebuah alternatif metode pengumpulan data kualitatif ilmu-ilmu sosial). At-Taqaddum, 8(1), 21. https://doi.org/10.21580/at.v8i1.1163

Hine, R. G., Hine, D. L., Kiesow III, K. A. F., Stutz, W. A., \& Hine, G. (2019). Float for connection to a swimmer in a wave powered vehicle (Patent No. US20190359305A1). https://patents.google.com/patent/US20190359305A1/en

Irmawati, N. L. (2018). Developing character of children with mental disabilities in sport learning. IJDS:Indonesian Journal of Disability Studies, 5(2), 152-156. https://doi.org/10.21776/ub.IJDS.2018.005.02.1

Kasih, A., Pamungkas, R., \& Nugroho, K. P. A. (2020). Survey of physical fitness level of the men's basketball team pre national sport Bangka Belitung 2020. Proceedings of the 1st Unimed International Conference on Sport Science (UnICoSS 2019), 138-140. https://doi.org/10.2991/ahsr.k.200305.039

Kotlyarov, A. (2019). The use of fins in initial training of swimmers aged 8-9 years. Proceedings of the 4th International Conference on Innovations in Sports, Tourism and Instructional Science (ICISTIS 2019). https://doi.org/10.2991/icistis-19.2019.34

Mirhan, M., \& Jusuf, J. B. K. (2016). Hubungan antara percaya diri dan kerja keras dalam olahraga dan keterampilan hidup. Jorpres (Jurnal Olahraga Prestasi), 12(1). https://doi.org/10.21831/jorpres.v12i1.9499

$\mathrm{Mu}$, Cao, Gong, Baiyin, \& Li. (2019). A classification method for fish swimming behaviors under incremental water velocity for fishway hydraulic design. Water, 11(10), 2131. https://doi.org/10.3390/w11102131

Opondo, S. O., \& Shapiro, M. J. (2019). Subalterns 'speak': migrant bodies, and the performativity of the arts. Globalizations, 16(4), 575-591. https://doi.org/10.1080/14747731.2018.1473373

Potop, V., Sima, E.-D., \& Manolachi, V. (2018). Learning the freestyle swimming at physical education and sport subject in the higher education of other profiles. Modern Journal of Language Teaching Methods (MJLTM), 8(7), 194-202. http://mjltm.org/files/site1/user_files_a9608a/admin-A-10-1-72-6b38a8a.pdf

Rezki, R., Jatra, R., \& SM, N. R. (2019). Analisis teknik renang gaya bebas pada mahasiswa mata kuliah renang Program Studi Penjaskesrek FKIP UIR. Journal Sport Area, 4(1), 259. https://doi.org/10.25299/sportarea.2019.vol4(1).2319

Saputra, S. A., Sukur, A., Tangkudung, J., Dlis, F., \& Widiastuti, W. (2019). The experiment of physical education teaching style on different categories of student confidence to improve the swimming learning value (Experimental method using design of treatment by factorial $3 \times 2$ ) at Higher School of Teacher Training and Pedagogy Kus. Journal of Education, Health and Sport, 9(6), 98-120. https://doi.org/10.5281/zenodo.3237944

Scurati, R., Michielon, G., Signorini, G., \& Invernizzi, P. L. (2019). Towards a Safe Aquatic Literacy: teaching the breaststroke swimming with mobile devices' support. A preliminary study. Journal of Physical Education and Sport, 19, 1999-2004.

Stets, A., Smith, S. L., \& Helton, W. S. (2020). Dual-task interference between swimming and verbal memory. Human Factors: The Journal of the Human Factors and Ergonomics Society, 62(7), 1132-1140. https://doi.org/10.1177/0018720819871743

Yani, M. A. H., Bayu Aji, S., Ariyanti, I. F., Sukaridhoto, S., Zainuddin, M. A., \& Basuki, A. (2019). Implementation of motion capture system for swimmer athlete monitoring. 2019 International Electronics Symposium (IES), 400-405. https://doi.org/10.1109/ELECSYM.2019.8901554

Zecha, D., Einfalt, M., \& Lienhart, R. (2019). Refining joint locations for human pose tracking in sports videos. 2019 IEEE/CVF Conference on Computer Vision and Pattern Recognition Workshops (CVPRW), 2524-2532. https://doi.org/10.1109/CVPRW.2019.00308 